\title{
KAJIAN PERBANDINGAN BUAH BLACK MULBERRY (Morus nigra L.) DENGAN AIR TERHADAP KARAKTERISTIK SPREADABLE PROCESSED CHEESE BLACK MULBERRY
}

\author{
Yusman Taufik, Sumartini, Winny Endriana \\ Program Studi Teknologi Pangan, Fakultas Teknik, Universitas Pasundan, Jl. Dr.Setiabudi No 93, Bandung, 40153, \\ Indonesia \\ E-mail : yusmantaufik@unpas.ac.id
}

Diterima pertama kali: 12 Januari 2020, Direvisi: 13 Januari 2020, Disetujui untuk publikasi: 16 Januari 2020

\begin{abstract}
Abstrak
Tujuan dari penelitian ini untuk menetapkan jumlah buah black mulberry dengan air yang tepat dalam pembuatan spreadable processed cheese black mulberry dengan karakteristik terbaik. Serta meningkatkan daya guna buah black mulberry menjadi bentuk olahan pangan yang awet dan meningkatkan usaha penganekaragaman produk makanan menjadi suatu produk yang dapat diterima oleh masyarakat. Metode penelitian yang dilakukan terdiri penelitian pendahuluan dan penelitian utama. Penelitian pendahuluan dilakukan untuk mendapatkan perbandingan natural cheese dan cheddar cheese yang paling optimal yang akan digunakan. Penelitian utama dilakukan untuk mendapatkan perbandingan buah black mulberry dengan air yang terbaik untuk karakteristik spreadable processed cheese black mulberry. Rancangan Acak Kelompok (RAK) yang terdiri dari satu faktor dengan 5 taraf. Jumlah perlakuan yang diberikan adalah 4 kali ulangan, yaitu faktor perbandingan buah black mulberry dengan air 2:1; 1,5:0,5; 1:1; 0,5:1,5; dan 1:2. Variable respon pada penelitian ini adalah uji organoleptik meliputi warna; aroma; tekstur; dan rasa. Respon kimia meliputi kadar protein, lemak, air, dan vitamin C. Respon fisik meliputi viskositas. Nilai gizi per sajian dalam 10 gram produk spreadable processed cheese black mulberry yang terpilih, memiliki energi total 38,86 kkal, protein 1,47 gram, lemak total 2,08 gram, dan karbohidrat total 3,55 gram.
\end{abstract}

Kata Kunci : Buah Black Mulberry, Air, Spreadable Processed Cheese

\section{Pendahuluan}

Spreadable Processed Cheese merupakan keju lunak dimana hasil akhirnya menjadi produk keju olahan yang dapat dioles pada suhu kamar. Standar minimal kandungan lemaknya sebagai produk spreadable processed cheese adalah $20 \%$ dengan kadar air antara 44-60\% (USFDA, CFR 133.179). Produk ini juga mengandung setidaknya $51 \%$ bahan keju. Selain bahan-bahan susu, pada produk ini dapat ditambahkan hidrokoloid, bahan pengatur keasaman, dan bahan pemanis. (Kapoor and Metzge, 2008). Keju olahan diproduksi dengan menggunakan keju alami dengan tingkat pematangan yang berbeda dan mencampurnya dengan bahan pengemulsi dalam kondisi panas, dalam hampa udara parsial atau pada tekanan ambien hingga homogen (Hladká et al., 2014). Pada pembuatan spreadable processed cheese ini menggunakan campuran keju cheddar natural dan olahan.

Buah black mulberry (Morus nigra L.) memiliki zat aktif antosianin yang berperan sebagai antioksidan dan memiliki senyawa-senyawa penting yang menguntungkan untuk bagi kesehatan manusia, diantaranya adalah kandungan cyanidin, yang berperan sebagai antosianin, insoquercin, sakarida, asam linoet, asam stearate, asam oleat, dan vitamin (Karotin, B1, B2, C) (Natalian, 2011). Dilihat dari karakter fisiknya, buah black mulberry merupakan buah memiliki rasa segar, manis, berwarna merah hingga keunguan dan buah black mulberry memiliki kadar antosianin hingga 1993 mg/100 g (Rahmasari, 2014). Antioksidan merupakan senyawa kimia yang dapat menyumbangkan satu atau lebih elektron kepada radikal bebas, sehingga radikal bebas dapat diredam sifat radikalnya (Hilwiyah, dkk, 2015).

Buah black mulberry yang sudah masak akan berwarna kehitaman dan teksturnya mudah hancur sehingga perlu mendapat perlakuan pengolahan (Rahmansari H. dan Wahono H. S., 2014). Buah black mulberry dapat diproduksi untuk dikonsumsi dalam keadaan segar maupun diolah menjadi buburbuah untuk diolah menjadi produk pangan fungsional. Penghancuran buah black mulberry menjadi bubur buah, tanpa adanya penyaringan dapat mengurangi limbah dan meningkatkan hasil produk buah. Bubur buah mulberry merupakan sumber antosianin dan antioksidan lainnya, serta menyediakan serat sehat pada produk pangan.

Air digunakan dalam pembuatan keju olahan untuk membantu proses pengolahan. Penambahan air dimaksudkan untuk mendapatkan kadar air keju akhir dengan memperhatikan kehilangan air yang tinggi, karena adanya penguapan pada saat pemasakan. (Kosikowski, 1994). Air diperlukan untuk mencapai atribut produk tertentu seperti kelembutan atau meltabilitas pada irisan keju olahan (Lee et al., 2004). Kandungan kadar air spreadable processed cheese menurut USFDA berkisar antara $44-60 \%$. Persyaratan 
pH air minum sesuai syarat mutu SNI 01-3553 2006 adalah berkisar 6,0-8,5.

Cheddar cheese memiliki standar $\mathrm{pH}$ optimum sekitar 5,20 - 5,25 (Daulay, 1991) yang digunakan sebagai bahan utama pembuatan spreadable processed cheeseini. Asam laktat atau asam lainnya dapat ditambahkan untuk mengatur $\mathrm{pH}$ (Zecher and Van Coillie, 1992). Nilai pH buah black mulberry spesies Morus nigra L. adalah 3,52. Sedangkan nilai $\mathrm{pH}$ jus buah dari black mulberry berkisar antara 3,52 - 5,60 (Ercisli dan Orhan, 2007). Namun, standard nilai $\mathrm{pH}$ dari produk spreadable processed cheese adalah $>4.0$ (Kapoor and Metzge, 2008). Soda kue dapat digunakan sebagai bahan tambahan pangan yang dapat digunakan untuk mengatur $\mathrm{pH}$ dari keju. Soda kue adalah senyawa kimia dengan rumus NaHCO Senyawa ini merupakan kristal yang sering terdapat dalam bentuk serbuk. Sifat dari soda kue adalah basa dan tidak memberi rasa, warna, dan bau pada makan yang dicampur dengan soda kue (Yunita, 2010).

Nilai $\mathrm{pH}$ terlalu tinggi pada pembuatan keju olahan akan menyebabkan terjadinya pelelehan yang sangat cepat bersamaan dengan keluarnya lemak secara berlebihan dan terbentuk keju seperti pudding dan berongga (Spreer, 1998). Sedangkan nilai $\mathrm{pH}$ yang rendah menyebabkan protein keju menggumpal sehingga meningkatkan kekenyalan keju olahan (Kosikowski, 1994). Oleh karena itu pengendalian $\mathrm{pH}$ yang tepat menjadi hal penting dalam pembuatan keju olahan (Barth, et al., 2017).

\section{Metode Penelitian}

Bahan-bahan yang digunakan dalam penelitian ini adalah bahan-bahan untuk pembuatan Spreadable Processed Cheese Black Mulberry dan bahan-bahan untuk analisis respon kimia.

Bahan-bahan yang digunakan untuk pembuatan Spreadable Processed Cheese Black Mulberry adalah Natural Cheese dengan merek Green Valley, Cheddar Cheese dengan merek Kraft Cheddar $2 \mathrm{~kg}$, black mulberry (Morus nigra L.) yang didapatkan dari perkebunan di kawasan Lembang-Bandung, air, minyak nabati, susu bubuk full cream, garam, gula, nisin, kasein bubuk, pati jagung, pengemulsi (disodium phosphate dan monosodium phosphate), dan asam laktat didapatkan dari toko sejati-Bandung.

Bahan-bahan yang digunakan untuk analisis kimia adalah batu didih, aquadest, amylum $1 \%$, larutan iodin 0,01 N, methanol, larutan DPPH (2,2-Dipenyl-1picrylhydrazyl) sebanyak $4 \mathrm{mg}$, larutan DPPH 0,5 mM, garam kjeldahl, garam selenium black, batu didih, $\mathrm{H} 2 \mathrm{SO} 4$ pekat, $\mathrm{Na} 2 \mathrm{~S} 2 \mathrm{O} 3, \mathrm{NaOH} 20 \%$, granula $\mathrm{Zn}, \mathrm{HCL}$ $0,1 \mathrm{~N}, \mathrm{NaOH} 0,1 \mathrm{~N}, \mathrm{~N}$-heksan, larutan luff schoolr, H2SO4 6N, KI, dan Na2S2O3 baku 0,1 N.

Alat-alat yang digunakan dalam penelitian ini adalah alat-alat untuk pembuatan Spreadable Processed Cheese Black Mulberry dan bahan-bahan untuk analisis respon kimia.
Alat-alat yang digunakan dalam pembuatan Spreadable Processed Cheese Black Mulberry yaitu alat timbangan, sendok, panci, pisau, cheese grater, spatula, blender, dan hand blender.

Alat-alat yang digunakan untuk analisis kimia yaitu kaca arloji, labu Erlenmeyer $100 \mathrm{ml}$, labu ukur 10 $\mathrm{ml}$, labu ukur $50 \mathrm{ml}$, beaker glass, batang pengaduk, pipet volumetric, pipet tetes, micropipette, vial, tabung reaksi, spektrofotometer UV-Vis neraca digital, cawan penguap, eksikator, oven, alat refluks, kertas saring, gelas kimia, corong, labu takar, labu Kjeldahl, kompor, adapter, alat destilasi, statif, klem, kantung sampel, benang kasur, sokhlet, kompor, penangas, labu dasar bundar, oven, eksikator, $\mathrm{pH}$ meter, viskometer ostwold.

Pada penelitian utama pembuatan Spreadable Processed Cheese Black Mulberry, perlakuan yang digunakan yaitu berdasarkan formulasi perbandingan Natural Cheese dan Cheddar Cheese terpilih dari penelitian pendahuluan. Rancangan perlakuan terdiri dari satu faktor, yaitu faktor perbandingan buah black mulberry dengan air (A) terdiri dari 5 taraf yaitu: a1 = buah black mulberry dengan air yaitu $2: 1$ a2 = buah black mulberry dengan air yaitu $1,5: 0,5$ a3 = buah black mulberry dengan air yaitu $1: 1$ a4 = buah black mulberry dengan air yaitu $0,5: 1,5$ a5 = buah black mulberry dengan air yaitu $1: 2$

Rancangan percobaan yang digunakan pada penelitian Spreadable Processed Cheese Black Mulberry adalah Rancangan Acak Kelompok (RAK) yang terdiri dari satu faktor dengan 5 taraf. Jumlah perlakukan yang diberikan adalah 4 kali, sehingga jumlah seluruh percobaan terdiri dari 20 kombinasi perlakuan.

Model percobaan untuk penelitian ini adalah sebagai berikut:

Dimana :

$$
\mathrm{Yij}=\mu+\mathrm{Kk}+\mathrm{Ai}+\varepsilon \mathrm{ij}
$$

Yij = Nilai pengamatan dari kelompok ke-k, yang memperoleh taraf ke-I dan faktor A (banyaknya perbandingan)

$\mu=$ Nilai tengah umum (rata-rata yang sebenarnya) dari nilai pengamatan

$\mathrm{Kk}=$ Pengaruh perlakuan dari kelompok ke-k

$\mathrm{Ai}=$ Pengaruh perlakuan dari taraf ke-I faktor $\mathrm{A}$ (banyaknya perbandingan)

cij = Pengaruh galat percobaan pada kelompok ke-k yang memperoleh taraf ke- i faktor A (banyaknya perbandingan)

$\mathrm{I}=$ Taraf tingkat perbandingan air dengan buahblack mulberry (a1, a2, a3, a4, a5)

$\mathrm{r}=$ Banyaknya ulangan $(4$ kali $)$

\section{Hasil dan Pembahasan \\ Hasil Penelitian Pendahuluan}

Penelitian pendahuluan dilakukan untuk menentukan perbandingan Natural Cheese dan Cheddar Cheese yang paling optimal yang akan digunakan dalam penelitian utama. Penelitian pendahuluan pembuatan Spreadable Processed Cheese menggunakan variasi 
Natural Cheese dengan Cheddar Cheese yaitu 2:1, 1:2, dan 1:1. Perbandingan Natural Cheese dengan Cheddar Cheese berpengaruh terhadap warna, aroma, tekstur, dan rasa dimana perbandingan Natural Cheese dengan Cheddar Cheese harus dikendalikan agar produk yang diinginkan didapat, semakin tinggi Cheddar Cheese maka enzim akan terus memecah substrat (lemak dan protein) sehingga hasil berupa tekstur akan semakin padat dan tidak lembut.

\section{Hasil Penelitian Utama}

Penelitian utama merupakan penelitian lanjutan dari penelitian pendahuluan. Pada penelitian utama dilakukan pengamatan spreadable processed cheese black mulberry dengan perbandingan buah Black Mulberry dengan air yang berbeda yaitu $2: 1,1,5: 0,5$, $1: 1,0,5: 1,5$, dan $1: 2$ dengan menggunakan perbandingan Natural Cheese dengan Cheddar Cheese 1 : 1 terpilih yang diperoleh dari penelitian pendahuluan. Penelitian utama yang dilakukan bertujuan untuk mengetahui pengaruh penambahan perbandingan buah Black Mulberry dengan air yang berbeda terhadap karakteristik organoleptik, kimia dan fisik Spreadable Processed Cheese Black Mulberry.

Spreadable Processed Cheese yang dihasilkan, dilakukan pengujian secara organoleptik untuk mengetahui tingkat kesukaan panelis terhadap produk dengan metode uji hedonik dengan parameter yang digunakan yaitu atribut warna, tekstur, aroma, dan rasa. Selanjutnya dilakukan analisis kimia meliputi kadar protein, kadar lemak, kadar air, kadar vitamin $\mathrm{C}$ dan aktivitas antioksidan pada produk terpilih. Serta dilakukan analisis secara fisik yaitu uji viskositas dan uji kalorimetri.

\section{Respon Organoleptik}

Pengujian organoleptik dengan metode uji hedonik ini dilakukan untuk mengetahui tingkat kesan kesukaan yang menyangkut produk sehingga dapat mengetahui produk tersebut dapat diterima oleh masyarakat atau sebaliknya. Pengujian organoleptik ini dilakukan dengan melibatkan 30 orang panelis untuk mengetahui kesan yang ditimbulkan panelis yang mewakili masyarakat atau konsumen terhadap atribut warna, tekstur, aroma dan rasa dari Spreadable Processed Cheese Black Mulberry.

Warna

Uji Hedonik

Suatu bahan makanan yang dinilai bergizi, enak, dan teksturnya sangat baik tidak akan dimakan apabila memiliki warna yang tidak sedap dipandang atau memberi kesan menyimpang dari warna yang seharusnya. Warna merupakan faktor visual yang pertama kali diperhitungkan dan terkadang merupakan faktor yang menentukan kualitas suatu makanan (Winarno, 2004).
Berdasarkan tabel ANAVA (lampiran 13) menunjukkan bahwa terdapat pengaruh nyata dari perbandingan buah black mulberry dengan air terhadap warna spreadable processed cheese black mulberry, sehingga perlu dilakukan uji lanjut Duncan, dapat dilihat pada Tabel 1.

Tabel 1. Data Hasil Uji Lanjut Perbandingan Buah Black Mulberry dengan Air Terhadap Warna Spreadable Processed Cheese

\begin{tabular}{|c|c|c|}
\hline $\begin{array}{c}\text { Perbandingan Buah } \\
\text { Black Mulberry } \\
\text { dengan Air }\end{array}$ & $\begin{array}{c}\text { Nilai Asli Rata- } \\
\text { Rata Warna }\end{array}$ & $\begin{array}{c}\text { Taraf } \\
\text { Nyata 5\% }\end{array}$ \\
\hline $\mathbf{a}_{\mathbf{1}}(\mathbf{2}: \mathbf{1})$ & 4,52 & $\mathrm{~b}$ \\
\hline $\mathbf{a}_{\mathbf{2}}(\mathbf{1 , 5}: \mathbf{0 , 5})$ & 4,71 & $\mathrm{~b}$ \\
\hline $\mathbf{a}_{\mathbf{3}}(\mathbf{1}: \mathbf{1})$ & 4,63 & $\mathrm{~b}$ \\
\hline $\mathbf{a}_{\mathbf{4}}(\mathbf{0 , 5}: \mathbf{1}, \mathbf{5})$ & 3,89 & $\mathrm{a}$ \\
\hline $\mathbf{a}_{\mathbf{5}}(\mathbf{1}: \mathbf{2})$ & 3,91 & $\mathrm{a}$ \\
\hline
\end{tabular}

Keterangan: Nilai rata-rata diikuti dengan huruf yang berbeda menunjukan perbedaan nyata menurut uji lanjut Duncan pada taraf 5\%.

Penerimaan warna suatu bahan berbeda-beda tergantung dari faktor alam, geografis, dan aspek sosial masyarakat penerima. Faktor-faktor yang menyebabkan suatu bahan makanan berwarna adalah pigmen alami yang terdapat dalam bahan pangan tersebut (Winarno, 2004).

Warna suatu bahan dipengaruhi oleh adanya cahaya yang diserap dan dipantulkan dari bahan itu sendiri dan juga ditentukan oleh faktor tiga dimensi yaitu warna produk, kecerahan dan kejelasan warna produk (Asfiyak, 2004).

\section{Uji Kolorimetri}

Kolorimetri adalah metode perbandingan menggunakan perbedaan warna. Metode kolorimetri mengukur warna suatu zat sebagai perbandingan. Biasanya cahaya putih digunakan sebagai sumber cahaya untuk membandingkan absorpsi cahaya relatif terhadap suatu zat. Salah satu alat yang digunakan untuk mengukur perbandingan warna yang tampak adalah kolorimeter. Kelebihan metode kolorimetri adalah kemudahannya dalam menetapkan kuantitas zat yang sangat kecil. Metode kolorimetri memiliki batas atas pada penetapan konstituen yang ada dalam kuantitas yang kurang dari satu atau dua persen. Salah satu faktor utama dalam metode kolorimetri adalah intensitas warna yang harus proporsional dengan konsentrasinya ( $\mathrm{J}$. Bassett, dkk, 1991).

Rerata tingkat kecerahan $\left(\mathrm{L}^{*}\right)$ warna uji kolorimetri spreadable processed cheese black mulberry berkisar antara 50.16 - 58.23. Berdasarkan tabel ANAVA (lampiran 13) menunjukkan bahwa terdapat pengaruh nyata dari perbandingan buah black mulberry dengan air terhadap tingkat kecerahan (L*) spreadable 
processed cheese black mulberry, sehingga perlu dilakukan uji lanjut Duncan, dapat dilihat pada Tabel 2.

Tabel 2. Hasil Uji Lanjut Duncan Perbandingan Buah Black Mulberry dengan Air Terhadap Tingkat Kecerahan (L*) Spreadable Processed Cheese

\begin{tabular}{|c|c|c|}
\hline $\begin{array}{c}\text { Perbandingan } \\
\text { Buah Black } \\
\text { Mulberry } \\
\text { dengan Air }\end{array}$ & $\begin{array}{c}\text { Nilai Asli Rata- } \\
\text { Rata } \\
\text { Kolorimetri L }\end{array}$ & Taraf Nyata 5\% \\
\hline a1 $(2: 1)$ & 51,66 & ab \\
\hline a2 $(1,5: 0,5)$ & 50,16 & $\mathrm{a}$ \\
\hline $\mathrm{a} 3(1: 1)$ & 52,97 & $\mathrm{ab}$ \\
\hline $\mathrm{a} 4(0,5: 1,5)$ & 58,23 & $\mathrm{c}$ \\
\hline $\mathrm{a} 5(1: 2)$ & 54,54 & $\mathrm{bc}$ \\
\hline
\end{tabular}

Keterangan: Nilai rata-rata diikuti dengan huruf yang berbeda menunjukan perbedaan nyata menurut uji lanjut Duncan pada taraf 5\%.

Notasi $L^{*}$ menyatakan parameter kecerahan (Lightness), dengan kisaran nilai 0-100 (hitam-putih). Analisis warna menggunakan alat colorimeter yang dilakukan pada spreadable processed cheese black mulberry ini tidak menggunakan kontrol, karena hanya bertujuan untuk membandingkan warna pada masingmasing perlakuan. Pada Tabel 22 menunjukkan bahwa semakin tinggi penambahan air terhadap buah black mulberry maka semakin tinggi tingkat kecerahan (Lightness) pada spreadable processed cheese black mulberry. Nilai rerata tingkat kecerahan paling tinggi diperoleh pada perbandingan buah black mulberry dengan air a4 $(0,5: 1,5)$ sebesar 58,23 sedangkan rerata tingkat kecerahan paling rendah pada perbandingan buah black mulberry dengan air a2 $(1,5: 0,5)$ sebesar 50,16. Penurunan tingkat kecerahan disebabkan banyaknya antosianin yang terekstrak seiring dengan besarnya volume pelarut yang digunakan.

Rerata tingkat kemerahan ( $\left.a^{*}\right)$ warna uji kolorimetri spreadable processed cheese black mulberry berkisar antara $2.94-7.00$. Berdasarkan tabel ANAVA (lampiran 13) menunjukkan bahwa terdapat pengaruh nyata dari perbandingan buah black mulberry dengan air terhadap tingkat kemerahan $\left(\mathrm{a}^{*}\right)$ spreadable processed cheese black mulberry, sehingga perlu dilakukan uji lanjut Duncan, dapat dilihat pada Tabel 3.

Tabel 3. Hasil Uji Lanjut Duncan Perbandingan Buah Black Mulberry dengan Air Terhadap Tingkat Kemerahan $\left(a^{*}\right)$ Spreadable Processed Cheese

\begin{tabular}{|c|c|c|}
\hline $\begin{array}{c}\text { Perbandingan } \\
\text { Buah Black } \\
\text { Mulberry } \\
\text { dengan Air }\end{array}$ & $\begin{array}{c}\text { Nilai Asli } \\
\text { Rata-Rata } \\
\text { Kolorimetri } \\
\mathrm{a}^{*}\end{array}$ & Taraf Nyata 5\% \\
\hline $\mathrm{a} 1(2: 1)$ & 6,33 & $\mathrm{~cd}$ \\
\hline $\mathrm{a} 2(1,5: 0,5)$ & 7,00 & $\mathrm{~d}$ \\
\hline $\mathrm{a} 3(1: 1)$ & 5,96 & $\mathrm{bc}$ \\
\hline $\mathrm{a} 4(0,5: 1,5)$ & 2,94 & $\mathrm{a}$ \\
\hline $\mathrm{a} 5(1: 2)$ & 5,05 & $\mathrm{~b}$ \\
\hline
\end{tabular}

Keterangan: Nilai rata-rata diikuti dengan huruf yang berbeda menunjukan perbedaan nyata menurut uji lanjut Duncan pada taraf 5\%.

Rerata tingkat kekuningan $\left(b^{*}\right)$ warna uji kolorimetri spreadable processed cheese black mulberry berkisar antara $-1,40-1.61$. Berdasarkan tabel ANAVA (lampiran 13) menunjukkan bahwa terdapat pengaruh nyata dari perbandingan buah black mulberry dengan air terhadap tingkat kekuningan $\left(b^{*}\right)$ spreadable processed cheese black mulberry, sehingga perlu dilakukan uji lanjut Duncan, dapat dilihat pada Tabel 4.

Tabel 4. Hasil Uji Lanjut Duncan Perbandingan Buah Black Mulberry dengan Air Terhadap Tingkat Kekuningan (b*) Spreadable Processed Cheese

\begin{tabular}{|c|c|c|}
\hline $\begin{array}{c}\text { Perbandingan } \\
\text { Buah Black } \\
\begin{array}{c}\text { Mulberry } \\
\text { dengan Air }\end{array}\end{array}$ & $\begin{array}{c}\text { Nilai Asli } \\
\text { Rata-Rata Uji } \\
\text { Kolorimetri } \\
\mathrm{b}^{*}\end{array}$ & Taraf Nyata 5\% \\
\hline $\mathbf{a}_{\mathbf{1}}(\mathbf{2}: \mathbf{1})$ & $-0,56$ & $\mathrm{~b}$ \\
\hline $\mathbf{a}_{\mathbf{2}}(\mathbf{1 , 5}: \mathbf{0 , 5})$ & $-1,40$ & $\mathrm{a}$ \\
\hline $\mathbf{a}_{\mathbf{3}}(\mathbf{1}: \mathbf{1})$ & $-0,21$ & $\mathrm{c}$ \\
\hline $\mathbf{a}_{\mathbf{4}}(\mathbf{0 , 5}: \mathbf{1 , 5})$ & 1,61 & $\mathrm{~d}$ \\
\hline $\mathbf{a}_{\mathbf{5}}(\mathbf{1}: \mathbf{2})$ & 1,36 & $\mathrm{~d}$ \\
\hline
\end{tabular}

Keterangan: Nilai rata-rata diikuti dengan huruf yang berbeda menunjukan perbedaan nyata menurut uji lanjut Duncan pada taraf $5 \%$.

Notasi b* menyatakan warna kromatik campuran biru-kuning, dengan nilai 0 sampai +70 untuk warna kuning dan nilai dari 0 sampai -70 untuk warna biru. Semakin besar penambahan buah black mulberry maka semakin rendah nilai $b^{*}$ yang diperoleh, yang menunjukkan produk mengarah ke warna kuning. Semakin rendah penambahan buah black mulberry maka semakin tinggi nilai $b^{*}$ yang diperoleh, yang menunjukkan produk mengarah ke warna biru.

Warna dan stabilitas pigmen antosianin tergantung pada struktur molekul secara keseluruhan. Substitusi struktur antosianin A dan B akan berpengaruh pada warna. Pada kondisi asam warna antosianin ditentukan oleh banyaknya substitusi pada cincin B. Semakin banyak substitusi $\mathrm{OH}$ dapat menyebabkan warna semakin biru, sedangkan metoksilasi akan menyebabkan warnanya semakin merah (Sudjana 1996). Kestabilan antosianin dipengaruhi oleh beberapa faktor antara lain $\mathrm{pH}$, suhu, cahaya, dan oksigen (Basuki dkk, 2005). Menurut Clydesdale (1998) dan Markakis (1982) Pigmen antosinanin (merah, ungu dan biru) merupakan molekul yang tidak stabil jika terjadi perubahan pada suhu, $\mathrm{pH}$, oksigen, cahaya, dan gula.

\section{Aroma}

Aroma merupakan salah satu parameter dalam penentuan kualitas suatu makanan. Aroma yang khas dapat dirasakan oleh indra penciuman tergantung dari bahan penyusun dan bahan yang ditambahkan pada 
makanan tersebut (Fellows, 1990). Aroma adalah rasa dan bau yang sangat subyektif serta sulit diukur, karena setiap orang mempunyai sensitifiras dan kesukaan yang berbeda. Dalam banyak hal, enaknya suatu makanan ditentukan oleh aroma makanan.

Berdasarkan tabel ANAVA (lampiran 13) menunjukkan bahwa tidak terdapat pengaruh nyata dari perbandingan buah black mulberry dengan air terhadap aroma Spreadable Processed Cheese Black Mulberry. Adapun nilai asli rata-rata uji hedonik terhadap aroma Spreadable Processed Cheese Black Mulberry dapat dilihat pada tabel 5 .

Tabel 5. Nilai Rata-rata Uji Hedonik Terhadap Aroma Spreadable Processed Cheese Black Mulberry

\begin{tabular}{|c|c|}
\hline $\begin{array}{c}\text { Perbandingan Buah } \\
\text { Black Mulberry } \\
\text { dengan Air }\end{array}$ & $\begin{array}{c}\text { Nilai Asli Rata-Rata } \\
\text { Aroma }\end{array}$ \\
\hline $\mathrm{a}_{1}(2: 1)$ & 4,38 \\
\hline $\mathrm{a}_{2}(1,5: 0,5)$ & 4,52 \\
\hline $\mathrm{a}_{3}(1: 1)$ & 4,73 \\
\hline $\mathrm{a}_{4}(0,5: 1,5)$ & 4,43 \\
\hline $\mathrm{a}_{5}(1: 2)$ & 4,40 \\
\hline
\end{tabular}

Keterangan: Nilai rata-rata diikuti dengan huruf yang berbeda menunjukan perbedaan nyata menurut uji lanjut Duncan pada taraf 5\%.

Hal ini berarti tidak ada perbedaan dalam pengaruh perlakuan perbandingan buah black mulberry dengan air terhadap aroma Spreadable Processed Cheese Black Mulberry. Walaupun demikian berdasarkan Tabel 5, aroma spreadable processed cheese black mulberry yang lebih disukai adalah pada sampel a3 (1: 1) dengan nilai asli rata-rata sebesar 4,73.

Tidak adanya pengaruh perlakuan perbandingan buah black mulberry dengan air ini disebabkan oleh variasi perbandingan buah black mulberry dengan air memiliki perlakuan yang hanya sedikit perbedaannya. Komposisi senyawa volatil yang larut dalam air sebenarnya masih bisa tercium walaupun ada perbedaan nilai rata-rata tetapi hanya sedikit, sehingga tidak menimbulkan perbedaan yang nyata antar perlakuan.

\section{Tekstur}

Tekstur merupakan segi penting dari mutu makanan, kadang-kadang lebih penting dari pada aroma, rasa dan warna. Tekstur suatu bahan makanan akan mempengaruhi cita rasa yang ditimbulkan oleh bahan tersebut. Perubahan tekstur suatu bahan dapat mengubah rasa dan bau yang timbul karena dapat mempengaruhi kecepatan timbulnya rangsangan terhadap kelenjar air liur (Winarno, 2004).

Berdasarkan tabel ANAVA (lampiran 13) menunjukkan bahwa terdapat pengaruh nyata dari perbandingan buah black mulberry dengan air terhadap tekstur Spreadable Processed Cheese Black Mulberry, sehingga perlu dilakukan uji lanjut Duncan dapat dilihat pada Tabel 6.
Tabel 6. Hasil Uji Lanjut Duncan Perbandingan Buah Black Mulberry dengan Air Terhadap Tekstur Spreadable Processed Cheese

\begin{tabular}{|c|c|c|}
\hline $\begin{array}{c}\text { Perbandingan } \\
\text { Buah Black } \\
\text { Mulberry } \\
\text { dengan Air }\end{array}$ & $\begin{array}{c}\text { Nilai Asli } \\
\text { Rata-Rata } \\
\text { Tekstur }\end{array}$ & Taraf Nyata 5\% \\
\hline $\mathbf{a}_{\mathbf{1}}(\mathbf{2}: \mathbf{1})$ & 4,38 & $\mathrm{~b}$ \\
\hline $\mathbf{a}_{\mathbf{2}}(\mathbf{1 , 5}: \mathbf{0 , 5})$ & 4,13 & $\mathrm{ab}$ \\
\hline $\mathbf{a}_{\mathbf{3}}(\mathbf{1}: \mathbf{1})$ & 4,03 & $\mathrm{a}$ \\
\hline $\mathbf{a}_{\mathbf{4}}(\mathbf{0 , 5}: \mathbf{1 , 5})$ & 4,88 & $\mathrm{c}$ \\
\hline $\mathbf{a}_{\mathbf{5}}(\mathbf{1}: \mathbf{2})$ & 4,36 & $\mathrm{~b}$ \\
\hline
\end{tabular}

Keterangan: Nilai rata-rata diikuti dengan huruf yang berbeda menunjukan perbedaan nyata menurut uji lanjut Duncan pada taraf 5\%.

Perbandingan buah black mulberry dengan air berpengaruh nyata terhadap tekstur Spreadable Processed Cheese Black Mulberry, untuk perbandingan yang terpilih a4 $(0,5: 1,5)$ buah Black Mulberry dengan air memiliki rata-rata yang lebih tinggi yakni 4,88 , hal ini disebabkan tekstur yang dihasilkan lebih lembut dibandingkan dengan perlakuan yang lainnya karena air yang ditambahkan lebih tinggi.

Rasa

Adapun nilai asli rata-rata uji hedonik terhadap rasa spreadable processed cheese black mulberry dapat dilihat pada tabel 7 .

Tabel 7. Nilai Rata-rata Uji Hedonik Terhadap Rasa Spreadable Processed Cheese Black Mulberry

\begin{tabular}{|c|c|}
\hline $\begin{array}{c}\text { Perbandingan } \\
\text { Buah Black } \\
\text { Mulberry } \\
\text { dengan Air }\end{array}$ & Nilai Asli Rata-Rata Rasa \\
\hline $\mathrm{a}_{1}(2: 1)$ & 4,40 \\
\hline $\mathrm{a}_{2}(1,5: 0,5)$ & 4,26 \\
\hline $\mathrm{a}_{3}(1: 1)$ & 4,32 \\
\hline $\mathrm{a}_{4}(0,5: 1,5)$ & 4,18 \\
\hline $\mathrm{a}_{5}(1: 2)$ & 3,97 \\
\hline
\end{tabular}

Keterangan: Nilai rata-rata diikuti dengan huruf yang berbeda menunjukan perbedaan nyata menurut uji lanjut Duncan pada taraf 5\%.

Hasil analisis sumber variansi (ANAVA) menunjukkan $\mathrm{F}$ hitung pada perlakuan perbandingan buah black mulberry dengan air tidak berpengaruh nyata, maka dapat diputuskan untuk menerima atau mempertahankan H0. Hal ini berarti tidak ada perbedaan dalam pengaruh perlakuan perbandingan buah black mulberry dengan air terhadap rasa Spreadable Processed Cheese Black Mulberry. Walaupun demikian berdasarkan Tabel 7, aroma spreadable processed cheese black mulberry yang lebih disukai adalah pada sampel a1 $(2: 1)$ dengan nilai asli rata-rata sebesar 4,40 . 
Namun dari hasil uji hedonik menunjukkan bahwa tidak adanya pengaruh rasa terhadap perlakuan dari perbedaan perbandingan buah black mulberry dengan air, hal ini disebabkan karena rasa yang dominan yang muncul adalah rasa kejunya. Rasa asam yang timbul dari penambahan buah black mulberry memberikan efek asam alami yang menyegarkan pada produk Spreadable Processed Cheese Black Mulberry.

Rasa dipengaruhi oleh beberapa faktor seperti senyawa kimia, suhu, dan interaksi dengan komponen rasa yang lainnya. Berbagai senyawa kimia menumbuhkan rasa yang berbeda. Rasa manis ditimbulkan oleh senyawa organik aliafatik yang mengandung gugus $\mathrm{OH}$ - seperti alkohol, beberapa asam amino dan gliserol. Rasa asam disebabkan oleh ion $\mathrm{H}+$. Sumber rasa manis yang utama adalah sukrosa, sumber rasa asam adalah asam sitrat, sedangkan kandungan serat menimbulkan (Mouth Feel) rasa berisi (Winarno, 2004).

\section{Respon Kimia}

Kadar Protein

Berdasarkan tabel ANAVA (lampiran 14) menunjukkan bahwa terdapat pengaruh nyata dari perbandingan buah black mulberry dengan air terhadap kadar protein (\%) Spreadable Processed Cheese Black Mulberry, sehingga perlu dilakukan uji lanjut Duncan dapat dilihat pada Tabel 8.

Tabel 8. Data Hasil Uji Lanjut Perbandingan Buah Black Mulberry dengan Air Terhadap Kadar Protein (\%) Spreadable Processed Cheese

\begin{tabular}{|c|c|c|}
\hline $\begin{array}{c}\text { Perbandingan } \\
\text { Buah Black } \\
\begin{array}{c}\text { Mulberry } \\
\text { dengan Air }\end{array}\end{array}$ & $\begin{array}{c}\text { Nilai Asli } \\
\text { Rata-Rata } \\
\text { Kadar } \\
\text { Protein }(\%)\end{array}$ & Taraf Nyata 5\% \\
\hline $\mathrm{a} 1(2: 1)$ & 14,78 & $\mathrm{~d}$ \\
\hline $\mathrm{a} 2(1,5: 0,5)$ & 15,81 & $\mathrm{e}$ \\
\hline $\mathrm{a} 3(1: 1)$ & 13,72 & $\mathrm{c}$ \\
\hline $\mathrm{a} 4(0,5: 1,5)$ & 11,58 & $\mathrm{a}$ \\
\hline $\mathrm{a} 5(1: 2)$ & 12,58 & $\mathrm{~b}$ \\
\hline
\end{tabular}

Keterangan: Nilai rata-rata diikuti dengan huruf yang berbeda menunjukan perbedaan nyata menurut uji lanjut Duncan pada taraf $5 \%$.

Buah black mulberry memiliki kandungan protein sebesar $1 \mathrm{~g} / 100$ gram (Afrianti, 2010). Berdasarkan hasil analisis bahan baku buah black mulberry didapatkan $0,78 \%$. Semakin banyak jumlah buah black mulberry yang ditambahkan maka $\mathrm{pH}$ yang terkandung dalam spreadable processed cheese black mulberry akan menjadi lebih asam. Walther (2008) menyatakan bahwa protein mudah mengalami kerusakan oleh pengaruh panas, goncangan, reaksi dengan asam atau basa kuat.

Perubahan kadar air berpengaruh terhadap kadar protein dari suatu bahan pangan. Berdasarkan penelitian ini perlakuan a4 $(0,5: 1,5)$ dengan perbandingan air lebih banyak dibanding dengan buah black mulberry, memiliki kandungan air dengan nilai rata-rata kadar air 56,74\% dan kadar protein $11,58 \%$, sedangkan perlakuan a2 $(1,5: 0,5)$ dengan perbandingan air lebih sedikit dengan buah black mulberry, memiliki kandungan air dengan nilai rata-rata kadar air 48,21\% dan kadar protein $15,81 \%$. Hal ini menyimpulkan bahwa semakin tinggi kadar air pada produk spreadable processed cheese black mulberry maka akan semakin rendah kadar protein yang terkandung. Berkurangnya kadar air, bahan pangan akan mengandung senyawasenyawa seperti protein, karbohidrat, lemak dan mineral dalam konsentrasi lebih tinggi (Winarno dkk, 1982).

\section{Kadar Lemak}

Berdasarkan tabel ANAVA (lampiran 14) menunjukkan bahwa terdapat pengaruh nyata dari perbandingan buah black mulberry dengan air terhadap kadar lemak (\%) Spreadable Processed Cheese Black Mulberry, sehingga perlu dilakukan uji lanjut Duncan dapat dilihat pada Tabel 9.

Tabel 9. Data Hasil Uji Lanjut Perbandingan Buah Black Mulberry dengan Air Terhadap Kadar Lemak (\%) Spreadable Processed Cheese

\begin{tabular}{|c|c|c|}
\hline $\begin{array}{c}\text { Perbandingan } \\
\text { Buah Black } \\
\text { Mulberry } \\
\text { dengan Air }\end{array}$ & $\begin{array}{c}\text { Nilai Asli } \\
\text { Rata-Rata } \\
\text { Kadar } \\
\text { Lemak }(\%)\end{array}$ & Taraf Nyata 5\% \\
\hline $\mathbf{a}_{\mathbf{1}}(\mathbf{2}: \mathbf{1})$ & 20,84 & $\mathrm{bc}$ \\
\hline $\mathbf{a}_{\mathbf{2}}(\mathbf{1 , 5}: \mathbf{0 , 5})$ & 21,17 & $\mathrm{c}$ \\
\hline $\mathbf{a}_{\mathbf{3}}(\mathbf{1}: \mathbf{1})$ & 20,67 & $\mathrm{~b}$ \\
\hline $\mathbf{a}_{\mathbf{4}}(\mathbf{0 , 5}: \mathbf{1 , 5})$ & 20,08 & $\mathrm{a}$ \\
\hline $\mathbf{a}_{5}(\mathbf{1}: \mathbf{2})$ & 20,49 & $\mathrm{~b}$ \\
\hline
\end{tabular}

Keterangan: Nilai rata-rata diikuti dengan huruf yang berbeda menunjukan perbedaan nyata menurut uji lanjut Duncan pada taraf 5\%.

Lemak berperanan penting pembentukan keju, semakin tinggi kadar lemak dalam susu maka keju yang dihasilkan akan semakin lembut, harum dan menarik. Sebaliknya jika kadar lemak rendah, keju yang dihasilkan akan keras dan berwarna pucat (Winarno, 2004).

Standar minimal kandungan lemaknya sebagai produk spreadable processed cheese adalah $20 \%$ (USFDA, CFR 133.179). Sumber kandungan lemak yang terdapat dalam produk spreadable processed cheese black mulberry berasal dari formulasi bahan tetap yaitu minyak nabati, padatan susu bubuk, natural cheese, dan cheddar cheese. Maka nilai kadar air pada semua perlakuan spreadable processed cheese black mulberry memenuhi syarat. Rata-rata kandungan kadar lemak pada perlakuan berkisar antara 20,08 - 21,17\%. Maka nilai kadar lemak pada semua perlakuan spreadable processed cheese black mulberry memenuhi syarat. 
Pada proses pembuatan keju olahan terdapat kemungkinan lemak keluar dari keju olahan selama proses pemanasan apabila temperatur lebih dari $80 \mathrm{oC}$, jadi semakin tinggi temperatur pemanasan maka semakin banyak lemak yang keluar (Fox et al., 2000).

\section{Kadar Air}

Kadar air merupakan faktor yang sangat penting untuk menentukan tekstur keju, yaitu kadar air yang semakin meningkat akan menyebabkan tekstur semakin lunak (Buckle et al., 1992).

Berdasarkan tabel ANAVA (lampiran 14) menunjukkan bahwa terdapat pengaruh nyata dari perbandingan buah black mulberry dengan air terhadap kadar air (\%) spreadable processed cheese black mulberry, sehingga perlu dilakukan uji lanjut Duncan dapat dilihat pada Tabel 10.

Tabel 10. Hasil Uji Lanjut Duncan Perbandingan Buah Black Mulberry dengan Air Terhadap Kadar Air (\%) Spreadable Processed Cheese

\begin{tabular}{|c|c|c|}
\hline $\begin{array}{c}\text { Perbandingan } \\
\text { Buah Black } \\
\text { Mulberry } \\
\text { dengan Air }\end{array}$ & $\begin{array}{c}\text { Nilai Asli } \\
\text { Rata-Rata } \\
\text { Kadar Air } \\
(\%)\end{array}$ & Taraf Nyata 5\% \\
\hline $\mathbf{a}_{\mathbf{1}}(\mathbf{2}: \mathbf{1})$ & 49,75 & $\mathrm{a}$ \\
\hline $\mathbf{a}_{\mathbf{2}}(\mathbf{1 , 5}: \mathbf{0 , 5})$ & 48,21 & $\mathrm{a}$ \\
\hline $\mathbf{a}_{\mathbf{3}}(\mathbf{1}: \mathbf{1})$ & 51,58 & $\mathrm{~b}$ \\
\hline $\mathbf{a}_{\mathbf{4}}(\mathbf{0 , 5}: \mathbf{1 , 5})$ & 56,74 & $\mathrm{c}$ \\
\hline $\mathbf{a}_{\mathbf{5}}(\mathbf{1}: \mathbf{2})$ & 53,47 & $\mathrm{bc}$ \\
\hline
\end{tabular}

Keterangan: Nilai rata-rata diikuti dengan huruf yang berbeda menunjukan perbedaan nyata menurut uji lanjut Duncan pada taraf 5\%.

Berdasarkan pengamatan hasil kadar air yang didapatkan, bahwa semua perlakuan pada penelitian utama dengan penambahan buah black mulberry yang semakin tinggi maka terjadi penurunan kadar air. Hal ini terjadi dikarenakan penambahan buah black mulberry menambah kandungan padatan total dalam formulasi dan akibatnya persentase kadar air menurun. Menurut El-Aziz dkk, 2012, penambahan makanan terhadap produk meningkatkan kandungan padatan total dalam formulasi keju, sehingga menyebabkan penurunan kelembaban.

Kadar air analisis bahan baku buah black mulberry adalah $64.29 \%$, dimana semakin tinggi konsentrasi buah black mulberry yang ditambahkan maka total padatan yang terkandung dalam spreadable processed cheese black mulberry semakin tinggi, sehingga kadar air semakin menurun. Meskipun komponen air yang terdapat di dalam buah black mulberry seperti intrasel atau ekstrasel dalam buah menjadi medium pendispersi atau pelarut dalam produk spreadable processed cheese black mulberry. Prescott et al., (2002) melaporkan bahwa dengan menambahkan zat terlarut, air dapat dibuat kurang tersedia. Kandungan air atau uap air dari suatu makanan mempengaruhi sifat fisik dan kimia seperti struktur, penampilan dan rasa dari produk makanan.

Kadar air spreadable processed cheese black mulberry berkisar antara 48,21 - 56,74. Standar minimal kandungan kadar air sebagai produk spreadable processed cheese adalah antara $44-60 \%$ (USFDA, CFR 133.179). Maka nilai kadar air pada semua perlakuan spreadable processed cheese black mulberry memenuhi syarat. Dimana kandungan kadar air tertinggi terdapat pada perbandingan buah black mulberry dengan air 0,5 : 1,5 berkisar antara 54,42 - 59,76\%, dengan rata-rata kadar air sebesar 56,74\%. Kadar air terendah terdapat pada perbandingan buah black mulberry dengan air 1,5:0,5 berkisar antara 47,04$49,11 \%$, dengan rata-rata kadar air sebesar 48,21\%.

\section{Kadar Vitamin C}

Vitamin adalah senyawa organik dalam jumlah mikro yang esensial di dalam fungsi kebanyakan bentuk ehidupan, tetapi tidak dapat disintesa oleh beberapa organisme dan harus diperoleh dari sumber dari luar tumbuh. Kebanyakan vitamin larut dalam air, berfungsi sebagai komponen berbagai koenzim, atau gugus prostetik enzim yang paling penting dalam metabolisme sel. Vitamin yang tergolong larut dalam air adalah vitamin $\mathrm{C}$ yang merupakan vitamin yang mudah rusak dari semua vitamin yang ada (Almatsier, 2009).

Berdasarkan tabel ANAVA (lampiran 14) menunjukkan bahwa terdapat pengaruh nyata dari perbandingan buah black mulberry dengan air terhadap kadar vitamin C (mg/100gram) spreadable processed cheese black mulberry, sehingga perlu dilakukan uji lanjut Duncan dapat dilihat pada Tabel 11.

Tabel 11. Hasil Uji Lanjut Duncan Perbandingan Buah Black Mulberry dengan Air Terhadap Kadar Vitamin C (mm/100gram) Spreadable Processed Cheese

\begin{tabular}{|c|c|c|}
\hline $\begin{array}{c}\text { Perbandingan } \\
\text { Buah Black } \\
\text { Mulberry dengan } \\
\text { Air }\end{array}$ & $\begin{array}{c}\text { Nilai Asli } \\
\text { Rata-Rata } \\
\text { Vitamin C } \\
(\mathrm{mg} / 100 \text { gram })\end{array}$ & $\begin{array}{c}\text { Taraf } \\
\text { Nyata 5\% }\end{array}$ \\
\hline $\mathbf{a}_{\mathbf{1}}(\mathbf{2}: \mathbf{1})$ & 6,01 & $\mathrm{~d}$ \\
\hline $\mathbf{a}_{\mathbf{2}}(\mathbf{1 , 5}: \mathbf{0 , 5})$ & 6,28 & $\mathrm{~d}$ \\
\hline $\mathbf{a}_{3}(\mathbf{1}: \mathbf{1})$ & 5,61 & $\mathrm{c}$ \\
\hline $\mathbf{a}_{\mathbf{4}}(\mathbf{0 , 5}: \mathbf{1 , 5})$ & 4,83 & $\mathrm{a}$ \\
\hline $\mathbf{a}_{\mathbf{5}}(\mathbf{1}: \mathbf{2})$ & 5,11 & $\mathrm{~b}$ \\
\hline
\end{tabular}

Keterangan: Nilai rata-rata diikuti dengan huruf yang berbeda menunjukan perbedaan nyata menurut uji lanjut Duncan pada taraf 5\%.

Total kandungan vitamin $\mathrm{C}$ pada spreadable processed cheese black mulberry ini belum dapat mencukupi kebutuhan tubuh akan kebutuhan vitamin $\mathrm{C}$ setiap harinya. Kebutuhan tubuh akan vitamin C berdasarkan RDA (Recommended Dietary Allowance) atau AKG (Angka Kecukupan Gizi) untuk pria dewasa 
dan wanita menurut National Academy of Science (2000) adalah 75-90 mg/hari.

$\mathrm{pH}$

Berdasarkan tabel ANAVA (lampiran 14) menunjukkan bahwa terdapat pengaruh nyata dari perbandingan buah black mulberry dengan air terhadap pH Spreadable Processed Cheese Black Mulberry, sehingga perlu dilakukan uji lanjut Duncan dapat dilihat pada Tabel 12.

Tabel 12. Data Hasil Uji Lanjut Perbandingan Buah Black Mulberry dengan Air Terhadap pH Spreadable Processed Cheese

\begin{tabular}{|c|c|c|}
\hline $\begin{array}{c}\text { Perbandingan } \\
\text { Buah Black } \\
\text { Mulberry } \\
\text { dengan Air }\end{array}$ & $\begin{array}{c}\text { Nilai Asli } \\
\text { Rata-Rata } \\
\mathrm{pH}\end{array}$ & Taraf Nyata 5\% \\
\hline $\mathbf{a}_{\mathbf{1}}(\mathbf{2}: \mathbf{1})$ & 5,70 & $\mathrm{~b}$ \\
\hline $\mathbf{a}_{\mathbf{2}}(\mathbf{1 , 5}: \mathbf{0 , 5})$ & 5,62 & $\mathrm{a}$ \\
\hline $\mathbf{a}_{\mathbf{3}}(\mathbf{1}: \mathbf{1})$ & 5,80 & $\mathrm{c}$ \\
\hline $\mathbf{a}_{\mathbf{4}}(\mathbf{0 , 5}: \mathbf{1 , 5})$ & 5,95 & $\mathrm{e}$ \\
\hline $\mathbf{a}_{\mathbf{5}}(\mathbf{1}: \mathbf{2})$ & 5,89 & $\mathrm{~d}$ \\
\hline
\end{tabular}

Keterangan: Nilai rata-rata diikuti dengan huruf yang berbeda menunjukan perbedaan nyata menurut uji lanjut Duncan pada taraf 5\%.

Berdasarkan hasil penilitian utama didapatkan $\mathrm{pH}$ spreadable processed cheese black mulberry memiliki pH berkisar antara 5,62 - 5,95. Standar nilai pH keju olahan berkisar antara 5,6 - 5,8 (Spreer, 1998), dengan demikian hasil yang didapatkan masuk dalam standar nilai $\mathrm{pH}$ keju olahan. Asam laktat atau asam lainnya dapat ditambahkan untuk mengatur $\mathrm{pH}$ (Zecher and Van Coillie, 1992). Pada tahap pengukuran $\mathrm{pH}$ sebelum dilakukan pemasakan ditambahan asam laktat dengan kisaran $7-8 \mathrm{ml}$ untuk masing-masing perlakuan untuk mencapai $\mathrm{pH}$ sesuai dengan standar.

Keasaman buah black mulberry dipengaruhi oleh kandungan asam yang menyusunnya seperti asamasam organik, salah satunya adalah kandungan asam askorbat, serta asam-asam lain. Dengan semakin berkurangnya kadar asam-asam yang terkandung di dalamnya menyebabkan nilai $\mathrm{pH}$ pun semakin meningkat (Utomo, 2013). Kondisi asam akan membantu proses penyusutan partikel untuk mengeluarkan whey lebih banyak, sehingga air yang dikeluarkanpun lebih banyak (Scoot, 1981).

\section{Respon Fisik}

\section{Uji Kekentalan}

Viskositas adalah suatu cara untuk menyatakan berapa daya tahan dari aliran yang diberikan oleh suatu cairan, di dalam zat cair viskositas dihasilkan oleh gaya kohesi antara molekul zat cair. Zat cair lebih kental (viskositasnya) daripada gas, sehingga untuk mengalirkan zat cair diperlukan gaya yang lebih besar daripada gas (Wylie, 1992). Viskositas merupakan ukuran kekentalan fluida yang menyatakan besar kecilnya gesekan yang terjadi dalam fluida. Makin besar viskositas suatu fluida, maka makin sulit suatu fluida mengalir dan makin sulit benda bergerak di dalam fluida tersebut (Suharyanto, 2012).

Berdasarkan tabel ANAVA (lampiran 15) menunjukkan bahwa terdapat pengaruh nyata dari perbandingan buah black mulberry dengan air terhadap viskositas (mPa.S) Spreadable Processed Cheese Black Mulberry, sehingga dilakukan uji lanjut Duncan, dapat dilihat pada Tabel 13.

Tabel 13. Data Hasil Uji Lanjut Perbandingan Buah Black Mulberry dengan Air Terhadap Viskositas (mPa.S) Spreadable Processed Cheese

\begin{tabular}{|c|c|c|}
\hline $\begin{array}{c}\text { Perbandingan } \\
\text { Buah Black } \\
\text { Mulberry } \\
\text { dengan Air }\end{array}$ & $\begin{array}{c}\text { Nilai Asli } \\
\text { Rata-Rata } \\
\text { Viskositas } \\
(\mathrm{mPa} . S)\end{array}$ & $\begin{array}{c}\text { Taraf Nyata } \\
5 \%\end{array}$ \\
\hline $\mathbf{a}_{\mathbf{1}}(\mathbf{2}: \mathbf{1})$ & 85,00 & $\mathrm{~d}$ \\
\hline $\mathbf{a}_{\mathbf{2}}(\mathbf{1 , 5}: \mathbf{0 , 5})$ & 107,50 & $\mathrm{e}$ \\
\hline $\mathbf{a}_{\mathbf{3}}(\mathbf{1}: \mathbf{1})$ & 72,50 & $\mathrm{c}$ \\
\hline $\mathbf{a}_{\mathbf{4}}(\mathbf{0 , 5}: \mathbf{1 , 5})$ & 45,00 & $\mathrm{a}$ \\
\hline $\mathbf{a} \mathbf{5}(\mathbf{1}: \mathbf{2})$ & 60,00 & $\mathrm{~b}$ \\
\hline
\end{tabular}

Keterangan: Nilai rata-rata diikuti dengan huruf yang berbeda menunjukan perbedaan nyata menurut uji lanjut Duncan pada taraf $5 \%$.

Berdasarkan penelitian yang dilakukan, viskositas spreadable processed cheese black mulberry dilihat dari perbandingan buah black mulberry dengan air digunakan, semakin banyak air yang ditambahkan maka jumlah senyawa organik dan bahan tambahan lain yang larut akan semakin sedikit, sehingga semakin sedikit senyawa yang larut dalam air maka viskositas spreadable processed cheese black mulberry yang didapatkan akan semakin tinggi atau sampel semakin pekat. Hal ini dapat disebabkan antara molekul-molekul ini saling tarik menarik dengan molekul air, membentuk ikatan hidrogen. Adanya ikatan hidrogen membuat air tidak lagi bergerak secara bebas, tetapi ada yang menahannya (Fennema, 1985, didalam yogi septiana, 2011). Semakin tinggi viskositas suatu bahan, maka bahan tersebut akan semakin stabil karena pergerakan partikel atau molekul cenderung sulit untuk bertumbukan dengan semakin kentalnya suatu bahan.

Data hasil viskositas spreadable processed cheese black mulberry yang didapatkan lebih kecil, hal ini dapat disebabkan karena beberapa faktor diantaranya dipengaruhi oleh kestabilan sampel yang semakin lama disimpan kestabilannya menurun, sehingga viskositas yang didapatkan semakin menurun.

Viskositas menentukan kemudahan suatu molekul bergerak karena adanya gesekan antar lapisan material. Karenanya viskositas menunjukkan tingkat 
ketahanan suatu cairan untuk mengalir. Semakin besar viskositas maka aliran akan semakin lambat. Besarnya viskositas dipengaruhi oleh beberapa faktor seperti temperatur, gaya tarik antar molekul dan ukuran serta jumlah molekul terlarut (Atkins, 2006).

Apabila zat cair tidak kental maka koefesiennya sama dengan nol sedangkan pada zat cair kental bagian yang menempel dinding mempunyai kecepatan yang sama dengan dinding. Bagian yang menempel pada dinding luar dalam keadaan diam dan yang menempel pada dinding dalam akan bergerak bersama dinding tersebut. Lapisan zat cair antara kedua dinding bergerak dengan kecepatan yang berubah secara linier sampai V. Aliran ini disebut aliran laminer. Aliran zat cair akan bersifat laminer apabila zat cairnya kental dan alirannya tidak terlalu cepat (Sudarjo, 2008).

\section{Keismpulan}

Berdasarkan hasil penelitian, dapat diambil kesimpulan sebagai berikut :

1. Hasil penelitian pendahuluan yang dilakukan dengan uji hedonik terhadap produk Spreadable Processed Cheese Black Mulberry dapat disimpulkan bahwa perlakuan yang terpilih adalah perlakuan $\mathrm{f}_{2}$ yaitu perbandingan Natural Cheese dengan Cheddar Cheese 1: 1 dari 35,2\% formulasi, sehingga perbandingan ini yang akan digunakan di penelitian utama.

2. Perbandingan buah black mulberry dengan air berpengaruh nyata terhadap karakteristik spreadable processed cheese black mulberry, meliputi respon organoleptik yaitu warna dan tekstur, respon kimia yaitu kadar protein, kadar lemak, kadar air, kadar vitamin $\mathrm{C}, \mathrm{pH}$, dan respon fisik yaitu viskositas.

3. Berdasarkan hasil kajian analisis terhadap respon organoleptik, respon kimia, dan respon fisik, produk perlakuan yang tepilih adalah perlakuan $a_{1}$ dengan perbandingan buah black mulberry dengan air $2: 1$ dari $43,25 \%$ formulasi. Nilai gizi per sajian dalam 10 gram produk spreadable processed cheese black mulberry yang terpilih, memiliki energi total 38,86 kkal, protein 1,47 gram, lemak total 2,08 gram, dan karbohidrat total 3,55 gram.

\section{Daftar Pustaka}

1. Afrianti, Leni Herliani. 2010. 33 Macam BuahBuahan Untuk Kesehatan. Penerbit CV Alfabeta. Bandung.

2. Almatsier, Sunita. 2009. Prinsip Dasar Ilmu Gizi. Edisi 8. PT. Gramedia Pustaka Utama. Jakarta.

3. Badan Standardisasi Nasional. 1992. SNI 01-2980 1992. Persyaratan Kandungan Keju. Badan Standardisasi Nasional. Jakarta (ID).
4. Basuki, N., Harijono, Kuswanto, dan Damanhuri. 2005. Studi Pewarisan Antosianin pada Ubi Jalar. Agravita 27 (1): 63 - 68. ISSN: 0126 - 0537.

5. Bylund, G. 2003. Dairy Processing Handbook. TetraPak Processing Systems AB. ISBN- 13:9789163134272

6. Cahyadi, Wisnu, 2012. Analisis dan Aspek Kesehatan Bahan Tambahan Pangan. Penerbit Bumi Aksara. Jakarta.

7. Codex STAN A-6-1978. Rev.1-1999. Codex General Standard for Cheesee. Codex Alimentarius

8. Daulay, D. 1991. Buku/Monograf Fermentasi Keju. PAU Pangan dan Gizi IPB. Bogor

9. Deny, Utomo. 2013. Komposisi Kimia Murbei. Jurnal Teknologi Pangan Vol 5. No 1. Fakultas Pertanian: Universitas Yudharta. Pasuruan.

10. Fachruddin, L., 1997, Membuat Aneka Abon. Kanisius. Yogyakarta.

11. Hui, Y.H. 2006. Handbook of Fruits and Fruit Processing. Blackwell Publishing. USA.

12. Spreer E. 1995. Milk and Dairy Product Technology. USA: Marcell Dekker Inc.

13. Sudarjo, Randy. 2008. Modul Praktikum Fisika Dasar I. Universitas Sriwijaya. Inderalaya.

14. Subhan, 2014. Analisis Kandungan Iodium Dalam Garam Butiran Konsumsi Yang Beredar Di Pasaran Kota Ambon. J Fikratuna

15. Sudjana, M.A. 1996. Metode Statistika. Penerbit Tarsito. Bandung

16. Sunanto, H. 1997. Budidaya Murbei dan Usaha Pensutraan Alam. Kansius. Yogyakarta.

17. Susilorini, Tri Eko dan Sawitri, M. E. 2007. Produk Olahan Susu. Penebar Swadaya. Jakarta .

18. Syafutri MI, F Pratama dan D Saputra. 2006. Sifat Fisik dan Kimia Buah Mangga (Mangifera indica L.) Selama Penyimpanan dengan Berbagai Metode Pengemasan. Jurnal Teknologi dan Industri Pangan 17(1).

19. Syafutri, Merynda Indriyani. 2008. Potensi Sari Buah Murbei (Morus alba L.) Sebagai Minuman Berantioksidan Serta Pengaruhnya Terhadap Kadar Kolesterol Dan Trigliserida Serum Tikus Percobaan. Tesis, Institut Pertanian Bogor

20. Syarief, R. dan H. Halid. 1992. Teknologi Penyimpanan Pangan. Kerjasama dengan Pusat Antar Universitas Pangan. Bogor. 